\title{
Lisansüstü Eğitim Alan Bireylerde Gelecek Kaygısı
}

\section{Osman TÜRKÖZ ${ }^{1 *}$, Meral BEKTAŞ ${ }^{2}$, Hüseyin ÇİÇEK ${ }^{3}$}

Geliş Tarihi/Received: 12.05 .2021

Kabul Tarihi/Accepted: 23.08.2021 Araştırma Makalesi/Research Article

\section{ÖZET}

$\mathrm{Bu}$ çalışma, lisansüstü eğitim alan bireylerin gelecek kaygısı ile ilgili görüşlerini ortaya koymayı amaçlamaktadır. Nitel yöntem ve fenomenolojik desen ile yürütülen çalışmada betimsel analiz tekniği kullanılmıştır. Çalışma, Burdur Mehmet Akif Ersoy Üniversitesi’nde lisansüstü eğitim alan 15 katılımcı ile görüşme yapılarak yürütülmüştür. Araştırma bulguları katılımcıların verdiği cevaplara göre yorumlanmıştır. Araştırma bulgularına göre katılımcıların lisansüstü eğitime akademisyen olmak için devam ettikleri ve gelecek kaygılarını azaltmak için kişisel gelişimlerine önem verdikleri ortaya çıkmıştır. Çalışma ile lisansüstü eğitim alan bireylere 1şık tutularak, literatüre katkı sunulacağı düşünülmektedir.

Anahtar Kelimeler: Lisansüstü Eğitim, Kaygı, Gelecek Kaygıs1

\section{Future Anxiety in Graduate Education Individuals}

\begin{abstract}
This study aims to reveal the views of postgraduate students about their future anxiety. Descriptive analysis technique was used in the study carried out with qualitative method and phenomenological design. The study was conducted by interviewing 15 participants who is receiving postgraduate education at Burdur Mehmet Akif Ersoy University. The research findings were interpreted according to the answers given by the participants. According to the

\footnotetext{
${ }^{1}$ Yüksek Lisans Öğrencisi, Burdur Mehmet Akif Ersoy Üniversitesi, Sosyal Bilimler Enstitüsü, İşletme Anabilim Dalı, Orcid No: 0000-0002-3029-4543

* Sorumlu yazar/Corresponding author

E-mail/e-ileti: osmanturkoz15@gmail.com

${ }^{2}$ Dr. Öğr. Üyesi, Burdur Mehmet Akif Ersoy Üniversitesi, Sosyal Bilimler Meslek Yüksekokulu, Büro Yönetimi ve Yönetici Asistanlığı Programı, Orcid No: 0000-0002-1616-8065

3 Doç. Dr., Burdur Mehmet Akif Ersoy Üniversitesi, İktisadi ve İdari Bilimler Fakültesi, İşletme Bölümü, Yönetim ve Organizasyon Anabilim Dalı, Orcid No: 0000-0002-8284-7955
} 


\section{Türköz, O., Bektaş, M., Çiçek, H.}

research findings, it was revealed that the participants continued their postgraduate education to become academicians and gave importance to their personal development in order to reduce their future anxieties. It is thought that this study will contribute to the literature by shedding light on individuals who receive postgraduate education.

Keywords: Postgraduate Education, Anxiety, Future Anxiety

\section{GíRiş}

Kaygı, bireyin iç ve dış dünyasında karşısına çıkabilecek fiziksel, zihinsel ve duygusal tepkimelerdir. Kaygı halinin olumsuz yönlerinin yanında olumlu yönleri de vardır (Özkan, 2021). Olumlu kaygı hali bireyin toplum içinde değerini artırmakla birlikte bireyin öğrenmeye karşı isteğini artırmaktadır(Akgün vd., 2007). Kaygı halinin sürekli ortaya çıkması bireyin geçmişinde önemli sorunları olduğunu göstermektedir. Her insanda kaygı durumu aynı şiddet de olmayabilir. Bu yüzden kaygı halini daha iyi kavrayabilmek için kaygının temeline ve nedenlerine odaklanmak gerekmektedir (Sürücü, 2012: 6-9).

Gelecek kaygısı ise gençlerin ve iş bulamayan bireylerin üzerinde stres oluşturan bir durum olarak karşılarına çıkmaktadır(Aydoğdu, 2021). Her dönemde farklı bir düzeylerde yaşanan kaygı durumu, üniversite çağlarının son zamanlarında iş bulamama, istenilen işi bulamama, bulunan işin beğenip beğenilmeyeceğinin sorgulaması sonucu oluşan kaygıdır. Bireyler, üniversite eğitimleri boyunca kaygı düzeylerini kontrol altında tutabilmek için kendilerine çeşitli yol haritaları çizmeye çalışırlar. Lisansüstü eğitime devam ederek kariyer basamaklarında yerlerini almak isteyen

Lisansüstü eğitim, lisans eğitiminden sonra öğrencinin ilgilendiği alanda eğitim, öğretim ve bilimsel araştırma faaliyetlerini içinde barındıran yüksek lisans eğitimi ile başlayan akabinde doktora eğitimi ile devam eden bir süreçtir. Lisansüstü eğitimin en temel amaçları arasında bilim insanı yetiştirmekle birlikte bilgi üreten, ürettiği bilgiyi kullanan, üretilen bilgileri bilimsel çerçevede eleştirebilen ve bu düşünce yapısıyla sorun çözebilen nitelikli insan gücünü topluma kazandırmaktır. Lisansüstü eğitim son yıllardaki okullaşma ile birlikte lisans öğrencilerinin tercihi haline gelmiştir. Bu öğrenci grupları içerisinde lisansüstü eğitimin gerçek amacını bilerek tamamlamak isteyen bireyler olduğu gibi bu eğitimi lisans eğitimi sonrasında gelecek kaygısını yenmek adına bir araç olarak kullanan bireylerde mevcuttur. Bireyler gelecek kaygısı sorununu yenmek için lisans eğitimlerinin yeterli olmayacağını ve bu nedenden dolayı lisansüstü eğitim alarak gelecek kaygılarını en aza indirmeyi hedeflemektedirler. 
Literatürde gelecek kaygısı ile ilgili çalışmalar bulunmakla birlikte, örneğin (Kula \& Saraç, 2016) üniversite öğrencilerinin gelecek kaygıları ile ilgili nicel çalışmasında üniversite öğrencilerinin kaygı düzeylerinin okul ortalaması, aile baskısı ve yer değişikliklerine göre kayg1 düzeyinin farklılık gösterip göstermediğini ortaya koymaya çalışmışladır. Üniversite öğrencilerinin kaygı düzeyleri ile ilgili literatürde farklı çalışmalar olmakla birlikte yapılan bu çalışma üniversitenin dördüncü sınıfta öğrencisi bulunan dört y1llık eğitim veren bütün fakülte/yüksekokul ve bölümlerini kapsaması yönüyle benzer çalışmalardan ayrılmaktadır.

$\mathrm{Bu}$ çalışmada ise lisansüstü eğitim alan bireylere nitel araştırma yöntemi olan fenomenoloji yöntemi ile sorular yöneltilerek, lisansüstü eğitim alan bireylerin gelecek kaygısı ile ilgili görüşleri ortaya koymaya çalışılmıştır.

\section{KAVRAMSAL ÇERÇEVE}

\subsection{Eğitim ve Lisansüstü Eğitim}

Eğitim, bilgi ile iç içe girerek, bireyin öğrenim kazanması veya öğretmesi yolu ile üst düzey bir yaşam kalitesine ulaşmasının, toplum içinde ilerlemesinin ilk basamağıdır (Özyılmaz, 2017: 35-41). Yani eğitim, kişinin kendi hareketleri ile yaşamı boyunca bilerek ve isteyerek kendisinde değişim getirme süreci olarak tanımlanabilir (Ertürk, 1988: 11-16).

Türkiye'nin çağdaş bir millet olma uğraşları düşünüldüğü zaman eğitimin gelişime olan katkıları çağdaş bir toplum olmanın temelini oluşturduğu görülmektedir. Eğitim sistemini, toplum ve toplumun gereksinimlerinden ayrı olarak düşünmek olası bir durum değildir. Bütün ülkelerin değişen üretim ve eğitim sistemlerine karşıllk verecek şekilde kendini yenilemesi gerekmektedir. Gelişen teknoloji ve değișen dünya ile birlikte eğitim sistemleri de yeniliğe ihtiyaç duymaktadırlar. (Çakmak, 2008: 33-41).

Eğitimi gerekli kılan unsurlar göz önüne alındığında, eğitimin amacı ile bağdaşan bilgi seviyesi yüksek, evrensel kültüre sahip, ruhsal ve bedensel olarak sağlıklı toplumlar yetiştirmek oldukça önem arz etmektedir. Bir toplumun üretkenliği, mutluluğu ve refahı eğitimle doğrudan ilişkilidir. Toplumda yer alan bireylerin sürekli ve nitelikli eğitim almasıyla edindikleri bilgi birikimleri, kazandıkları yetenekleri ile ekonomik büyümeye katkı sağlamaları bu unsurların gelişimine katkı sağlamaktadır. Bir diğer deyişle eğitim, sosyo-ekonomik ve sosyo-kültürel gelişim için en önemli itici güç ve verimliliğin artması için en önemli unsurdur (Özyılmaz, 2017: 35-41).

Türkiye' de eğitim sistemi ilköğretim ile başlayan zorunlu dört yıllık bir eğitim sürecini kapsayan farklı seçenekler ile çeşitliği olan imam-hatip ve orta oluşan öğrencilerin lise 


\section{Türköz, O., Bektaş, M., Çiçek, H.}

eğitimine hazırlığını sağlayan öğrencilerin kendi yetenek ve gelişimlerini sağlayarak tercihlerine göre seçmeli derslerden oluşan eğitim programıdır.

Ortaöğretim ile devam eden eğitim sisteminde mesleki ve teknik öğretim kurumlarının hepsini içinde barındırır (Milli Eğitim Bakanlığı, 2021). Lise eğitimini veya ona eşit bir programdan mezun olan öğrenciler yükseköğretim kurumuna girmek için hak kazanırlar. YÖK'ün yaptığı sınav ile elde edilen bu hakkı kazanmak için öğrencilerin belli bir puan alması gerekmektedir. Türkiye de yüksek eğitim kurumları üniversiteler, meslek yüksekokulları ve diğer eğitim enstitülerinden oluşur. Lisans eğitimini tamamlayan öğrenciler Yüksek Lisans Derecesi, Doktora Derecesi, Tıpta Uzmanlaşma ve Sanatta Yeterlilik programlarını kendi tercihleri doğrultusunda tamamlayarak eğitimin en üst seviyesine adım atmış olurlar (Anonim, 2020).

Lisansüstü eğitim, lisans eğitimine paralel olarak ilerleyen yüksek lisans ve doktora programları ile tıpta uzmanlık, sanat dallarında yapılan sanatta yeterlilik çalışmalarının gerektirdiği eğitim, bilimsel araştırma ve uygulama faaliyetlerini içinde barındıran eğitim olarak tanımlanabilir (Mevzuat Bilgi Sistemi-Lisansüstü Eğitim Yönetmeliği, n.d.).

Lisansüstü eğitim, 'üniversitede lisansüstü derecelere götüren, araştırma yoluyla bilgiye katkıda bulunacak ve gelişen toplumun gereksinimlerini karşılayacak bilim adamı ve öğretim elemanı yetiştirmeyi amaç edinen bir eğitim faaliyeti’ olarak tanımlanmaktadır (Varış, 1972: 124).

Ülkelerin kalkınma ve gelişme hedeflerini gerçekleştirebilmesi için bilim ve eğitimi senkronize bir şekilde tüm kurum ve kuruluşları ile etkin bir şekilde kullanması gerekmektedir. Lisansüstü eğitim bu iki kavramın kaynaştırılması açısından büyük önem taşımaktadır. Küresel değerleri içinde barından yüksek nitelikli insan gücünü eğitimleri ile karşılayamayan ülkeler toplumlarının ve kurumlarının geleceğini niteliksiz ve alanında yetersiz bireylere bırakmak zorunda kalacaklardır. Ülkelerin ihtiyacı olan bilim insanı ve akademisyenleri yetiştirmeyi amaç edinen lisansüstü eğitim, mutena bir eğitimdir. Farklı alanlarda görev alacak yönetici, akademisyen ve uzmanların bu eğitim kademesinde yetişmesi beklenmektedir. Bu nedenle lisansüstü eğitimin sosyal yararı gözetecek şekilde ve en verimli sonuçların elde edileceği biçimde verilmesi gerekmektedir (Sevinç, 2002: 1-13).

$\mathrm{Bu}$ çalışmada lisansüstü eğitim kavramı doktora ve yüksek lisans eğitimini tanımlamaktadır. Ülkemizde 2019-2020 öğretim y1lında 297.001 yüksek lisans ve 101.242 doktora öğrencisi eğitim görmektedir (YÖK, 2021). 


\subsection{Kaygi}

Kaygı, bir baskı altında fark edilen endişe ve stres hali olarak tanımlanabilir. Kaygı kavramı için başka bir tanım yapacak olursak kaygı, insan hayatını tehdit altına alan yada tehdit şeklinde algılanan veya çevresel durumlardan oluşan bir duygu durumudur (Büyüköztürk, 1997: 453-464).

Kaygının üç farklı şiddet boyutu bulunmaktadır. Bunlar; hafif kaygı, orta kaygı ve yüksek şiddetli kaygıdır. Hafif ve orta şiddetli kaygı bireyi isteklendiren, motive eden bir durum olarak karşımıza çıkmaktadır. Yüksek şiddetli kaygı durumunda ise kişi kendini çaresizlik içerinde hisseder bu durum birey için katlanılamaz bir durum olarak görülmektedir. Şiddetli kaygı durumunu daha çok güç kazanma isteği olan, yükselmeye çalışan ya da bulunduğu sosyal çevreye hükmetme isteği olan bireyler yaşamaktadırlar.

Kayg1, bireyi fiziksel ve çevresel tehditlere karşı uyaran, çevreye gerekli uyumu sağlamasına yardımcı olan ve yaşamını sürdürmesine katkı sağlayan ve insanı motive eden çok yönlü duygu durumlarını da içinde barındırmaktadır. İnsanlar için kaygı genellikle gelecekle ilgili olumsuzluk, karamsarlık, başarısızlık, endişe, umutsuzluk duyguları ile dile getirilen bir durum olarak karşımıza çıkmaktadır (Tektaş, 2014: 243-253).

\subsubsection{Kaygı Türleri}

Kaygı kavramı, bireylerin yaşam süreleri boyunca hemen hemen her bireyde görülebilen bir duygu halidir. Bu duygu hali bireyin kendisini tehlikede hissettiği durumlarda ortaya çıkmaktadır. Örnek vermek gerekirse kişi için çok fazla önem arz eden bir sınava girmeden önce sınav ile ilgili bir kaygı duyması veya kişinin gireceği bir ameliyattan önce sıkıntı içermesi kişide kaygı halini ortaya çıkarabilmektedir. Bu tarz kaygılar zaman açısından daha kısa sürelidir ve duruma göre geçici olabilmektedir. Bununla birlikte kişi normal günlük yaşamında bile kendisini huzursuz ve baskı altında hissedebilir. İşte bu kişiler sürekli kaygı yaşamaktadırlar. Bu sonuçlara bağlı olarak durumluk kaygı ve sürekli kaygı türleri ortaya ç1kmaktadır (Kartopu, 2013: 238-260).

Durumluk kaygıda, kişilerin duygusal durumları ortaya çıkmaktadır. Bu duygusal durum belirli bir seviyede var olmaktadır. Geçici olarak nitelendirilen durumluk kaygı bu kaygı türünü ortaya çıkaran etmenler tekrarlandığında tekrarlanabilir. Bu etmenler devam ettiğinde kayg1 durumunun süresi artabilmektedir (Spielberger vd., 1983:69-97).

Süreklilik kaygı durumunda kişinin bireysel özellikleri ve kişinin hayata bakış açıları devreye girmektedir. Durumluk kaygısının kinetik enerjiyle, sürekli kaygının ise potansiyel enerjiyle kısmi olarak benzerlik gösterdiği düşünülmektedir. Durumluk kaygısının kinetik enerjiyle benzer noktası belirli bir zaman içinde, belirli bir yoğunlukta, somut bir reaksiyonu 


\section{Türköz, O., Bektaş, M., Çiçek, H.}

ya da süreci ifade etmesidir. Sürekli kaygının potansiyel enerjiyle benzer noktası ise tepkilerdeki kişisel çeşitlilikleri ortaya koymasıdır (Spielberger vd., 1983: 69-97).

Durumluk kaygı halinin gerçekleşebilmesi için bireyin kendisini korku halinde hissetmesi gerekmektedir. Bir korku hali olarak ifade edilen bu durum sona erdiği zaman durumluk kaygı hali de sona ermektedir. Sürekli kaygı halinde ise kaygı durumu bireyin içinden gelmesi ile gerçekleşmektedir. Bireyin hayatı için vermiş olduğu kararlar veya geçmişteki seçimleri sürekli kaygının devam etmesine yol açabilmektedir (Akmaz \& Ceylan, 2009: 131147).

\subsubsection{Kaygı Nedenleri ve Sonuçları}

Duyguların sebeplerini kişilerin çevresini anlama şeklinden ayırt etmek imkansızdır. Kişi kendisini bulunduğu ortamda rahat ve refah hissederse kişinin kaygı duyması ortadan kalkmaktadır. Ancak bulunduğu ortamdaki diğer bireyler kendilerini rahat hissetmezler ise kaygı durumunu o kişiler yaşayabilirler. Kültür kişinin hangi ortamı nasıl algılayacağını öğretir. $\mathrm{Bu}$ sebeple bulunulan ortamın nasıl bir kaygı ortaya çıkaracağı kültürler arası farklılıklar gösterebilir (Kaya \& Varol, 1999: 37).

Cüceloğlu (1991) kaygının nedenlerini şu şekilde sıralamaktadır;

- $\quad$ Destek alan bireyin aldığı desteğinin ortadan kalkması.

- Bireyin negatif bir durumla karşılaşması halinde kaygının ortaya çıkması.

- Bireyin kendi gerçekleştirdiği bir iş ile kendi içinde tezatlık yaşaması durumunda kaygı ortaya çıkmaktadır.

- Gelecekle ilgili belirsizlik durumu bireyde kaygı durumunu ortaya çıkarmaktadır (akt. Kaya \& Varol, 1999: 37).

Ailelerin çocukları yetiştirme tarzlarının çocuk yetiştirme üzerine yapılan çalışmalarda anne babanın çocuklarına düşkünlüklerinin azlığı ve kısıtlayıcı olmaları kaygı seviyelerinin artmasında önemli bir etken oluşturmaktadır (Kozacıoğlu, 1986: 19-21).

Kaygı kavramı genel olarak kişinin kendisini tehdit eden bir durum ile karşılaştığında ortaya çıkmaktadır. Kişi kendisini baskı altında hissettiğinde buna tepki olarak kişi telaş ve kaygı durumu yaşayabilmektedir. Bunun sonucunda kaygının herkes tarafından yaşanabilecek bir durum olduğu görülmektedir. Ancak kaygı halinin bir başka durumu olan yüksek şiddetli kaygı halinde ise kişi de ruhsal bozukluklar meydana getirmektedir (Erözkan, 2011: 776-805). Kaygı bireylerde psikolojik durumlar ortaya çıkardığı gibi bireyin fizyolojik olarak etkilenmesine de yol açabilmektedir. Bu fizyolojik durumlar kalp atışında hızlanma, mide bulantısı, nefes alıp vermede zorluk, kemiklerde meydana gelen ağrılar olarak karşımıza çıkmaktadır (Spielberger \& Rickman, 1990: 69-97). 


\section{MAKÜ-BIFD 4(2), 132-152, 2021}

Kişinin yaşının kaç olduğunun önemi olmaksızın kaygı kişinin hayatını her yaşta etkileyebilmektedir. Kaygının şiddetinin çok fazla artma eğilimi göstermesi bireyin ilişki durumlarında olumsuz etkiler yaratmaktadır (Alisinanoğlu \& Ulutaş, 2003: 65-71). Kaygı halinin ortaya çıkardığı diğer bir sonuç ise kişiler geçmiş yaşamlarından etkilenebilir bu durum diğer insanlar tarafindan anlaşılmayan bir reaksiyondur (Doğan \& Baş, 2003:1-5). Kaygı halinin olumsuz sonuçları olduğu gibi olumlu sonuçları da bulunmaktadır. Kaygı sonucunda birey kendisini endişeli hissettiği zamanlarda bu endişe durumu kişiyi gerçekleştireceği işinde başarıya götürebilmektedir (Çetiner Aydın, 2019: 228-236).

\subsubsection{Gelecek Kaygısı}

Gelecek kaygısı, bilhassa genç nüfus üzerinde büyük baskı ve stres yaratan vaziyetler bütününü simgelemektedir. Genç bireylerin yaşamlarının ilerleyen zamanlarında hayatlarını nasıl idame ettireceklerini, yaptıkları işte mutlu olup olmayacaklarını çalıştıkları sektörün, zarar görüp görmeyeceğini ve buna benzer birçok soru nedeniyle sürekli bir sorgulama halinin olması gelecek kaygısını oluşturmaktadır.

Bandura (1991), öz yeterlilik teorisi içinde gelecek kaygısını bilişsel olarak yaklaşmaktadır. Gelecek kaygısını karşılaşılacak muhtemel zararlı durumlara karşı önceden tahmin edilebilir endişe durumu olarak tanımlamaktadır. Ona göre tehdit, algılanan başa çıkma yetenekleri ile çevrenin potansiyel olarak zararlı yönleri arasındaki eşleşmeyi yansıtan ilişkisel bir özelliktir. Potansiyel tehditler üzerinde kontrol sahibi olabileceklerine inanan insanlar kaygıları tarafından rahatsız edilmez ve endişe verici düşüncelere girmezler (Bandura, 1991: 89-110). Bandura'nın fikirlerini destekleyen benzer sonuçlar Lang, Shapiro ve Cobb (1991) tarafından yapılan çalışma neticesinde de ortaya çıkmıştır (Zaleski, 1996: 167).

Gelecek kaygısı, kısıtlı kaynakları olan hayatın son yıllarında özellikle rekabetin ve rakiplerin artmasıyla da ortaya çıkmaktadır. Ergenliğin ortalarında başlayan gelecekle ilgili sorgulamalar bireyin eğitim hayatının sonlanmasına yakın zamanlarda artmaktadır. Mezun olduktan hemen sonra uzun süre iş bulamayan ve geçim zorluğu çeken birey örnekleri düşünüldüğünde gelecek kaygısının özellikle lisans eğitiminin son yıllarında yüksek şiddetli hissedildiği düşünülmektedir (Akçok, 2018).

Gelecek kaygısı özellikle genç bireyler üstünde büyük bir etken olsa da tüm bireylerin hemen hemen her yaşta karşısına çıkabilecek stres oluşturan bir durumlar bütünüdür. Gelecek kaygısının nedenleri şu şekilde belirtilmektedir;

- $\quad$ Rekabetin çok fazla olması.

- $\quad$ Henüz ergenlik çağında olan bireylerin gelecek ile ilgili çok fazla sorgulama yapmalar1. 


\section{Türköz, O., Bektaş, M., Çiçek, H.}

- $\quad$ Uzun süre iş bulamamak.

- $\quad$ Bireyin yaşadığ $\quad$ ülkenin ekonomik temelinin sağlam olmaması.

- $\quad$ Sorumluluk duygusunun artmas1.

- $\quad$ Geçim sıkıntısı.

- $\quad$ İstediği eğitimi alamamak.

- $\quad$ İstediği mesleği icra edememek.

- $\quad$ Kişisel gelişimlerini tamamlayamamak (Akçok, 2021).

\section{AMAÇ VE YÖNTEM}

$\mathrm{Bu}$ çalışmanın amacı, lisansüstü eğitim alan bireylerin gelecek kaygısı ile ilgili görüşlerini ortaya koymaktır.

Çalışma, nitel bir çalışma olarak tasarlanmış ve nitel araştırma desenlerinden fenomenolojik desen ile hazırlanmıştır. Örneklem grubu, küme örneklemesi yöntemi kullanılarak belirlenmiş, veri toplama aracı olarak görüşme formu kullanılmıştır. Fenomenoloji, kişinin tecrübeleri ile temel oluşturan bir kavramdır. $\mathrm{Bu}$ yaklaşım yönteminde kişinin tecrübeleri ile birlikte olaylara anlam yüklemesini incelemektedir (Göçer, 2013). Yapılan çalışmada lisansüstü eğitim alan öğrencilerin gelecek kaygıları ile ilgili görüşlerini belirlemek amacıyla en uygun yöntemin görüşme tekniği olacağı düşünülmüştür. Görüşme yapılan katılımcıların bazılarına telekonferans yöntemi ile bazılarına ise yüz yüze ulaşılmış, çalışma konusu ve amaç hakkında bilgi verilmiştir. Bilgilendirme sonucunda görüşmeyi kabul eden katılımcılarla görüşme yapılmıştır. Görüşme odaklı yapılan bu nitel çalışmada şu hususlara dikkat edilmiştir;

- Katılımcılar araştırmaya gönüllü olarak dâhil edilmiştir.

- G Görüşmelerin bazıları, salgın hastalık dolayısıyla uzaktan gerçekleşmiştir.

\subsection{Katılımcilar}

Katılımcılar, lisansüstü eğitim alan 15 öğrenciden oluşmaktadır. Katılımcıların isimleri yerine takma isimler kullanılmıştır. 
Tablo 1. Katılımcılara ait bilgiler ve görüşme süreleri

\begin{tabular}{|c|c|c|c|c|c|}
\hline $\begin{array}{c}\text { Takma(Kod) } \\
\text { İsmi }\end{array}$ & $\begin{array}{l}\text { Lisansüstü Eğitim } \\
\text { Aldığı Bölüm }\end{array}$ & Cinsiyeti & Yaşı & $\begin{array}{l}\text { Lisansüstï Eğitimi } \\
\text { ve Eğitim Aldığı } \\
\text { Dönem }\end{array}$ & $\begin{array}{l}\text { Görüşme } \\
\text { Süresi }\end{array}$ \\
\hline Iş1l Hanım & $\begin{array}{l}\text { Beden Eğitimi } \\
\text { Öğretmenliği }\end{array}$ & Kadın & 23 & $\begin{array}{l}\text { Yüksek Lisans } \\
\text { 1.Dönem }\end{array}$ & $13: 25$ \\
\hline Ayşe Hanım & İşletme & Kadın & 24 & $\begin{array}{c}\text { Yüksek Lisans } \\
\text { 1.Dönem } \\
\end{array}$ & $12: 35$ \\
\hline Ünal Bey & İşletme & Erkek & 23 & $\begin{array}{c}\text { Yüksek Lisans } \\
\text { 1.Dönem }\end{array}$ & $12: 50$ \\
\hline Sabri Bey & Turizm Rehberliği & Erkek & 25 & $\begin{array}{l}\text { Yüksek Lisans } \\
\text { 1.Dönem }\end{array}$ & $10: 25$ \\
\hline Güneş Hanım & İktisat & Kadın & 24 & $\begin{array}{c}\text { Yüksek Lisans } \\
\text { 1.Dönem } \\
\end{array}$ & $13: 44$ \\
\hline Ali Bey & İşletme & Erkek & 25 & $\begin{array}{l}\text { Yüksek Lisans } \\
\text { 1.Dönem }\end{array}$ & $11: 53$ \\
\hline Erol Bey & İşletme & Erkek & 25 & $\begin{array}{l}\text { Yüksek Lisans } \\
\text { 1.Dönem }\end{array}$ & $35: 59$ \\
\hline Ayşe Hanım & İşletme & Kadın & 23 & $\begin{array}{c}\text { Yüksek Lisans } \\
\text { 1.Dönem }\end{array}$ & $9: 15$ \\
\hline Gamze Hanım & İşletme & Kadın & 22 & $\begin{array}{l}\text { Yüksek Lisans } \\
\text { 1.Dönem }\end{array}$ & $13: 17$ \\
\hline Oğuzhan Bey & Sağlık Yönetimi & Erkek & 24 & $\begin{array}{c}\text { Yüksek Lisans Tez } \\
\text { Dönemi }\end{array}$ & $14: 32$ \\
\hline Dilara Hanım & İşletme & Kadın & 26 & $\begin{array}{l}\text { Yüksek Lisans } \\
\text { 1.Dönem }\end{array}$ & $12: 36$ \\
\hline Fatih Bey & İşletme & Erkek & 25 & $\begin{array}{l}\text { Yüksek Lisans } \\
\text { 1.Dönem }\end{array}$ & $10: 15$ \\
\hline İrem Hanım & İşletme & Kadın & 22 & $\begin{array}{c}\text { Yüksek Lisans } \\
\text { 1.Dönem }\end{array}$ & $11: 47$ \\
\hline Ahmet Bey & $\begin{array}{l}\text { Beden Eğitimi } \\
\text { Öğretmenliği }\end{array}$ & Erkek & 26 & $\begin{array}{c}\text { Yüksek Lisans Tez } \\
\text { Dönemi }\end{array}$ & $10: 53$ \\
\hline $\begin{array}{l}\text { Ayşegül } \\
\text { Hanım }\end{array}$ & İşletme & Kadın & 24 & $\begin{array}{l}\text { Yüksek Lisans } \\
\text { 1.Dönem }\end{array}$ & $13: 20$ \\
\hline
\end{tabular}

Tablo 1'de görüldüğü gibi katılımcılardan 8'i kadın 7'si erkektir. Katılımcıların 10'u işletme alanında, 2'si beden eğitimi öğretmenliği alanında, 1'i sağlık yönetimi alanında, 1'i turizm rehberliği alanında, 1’i iktisat alanında lisansüstü eğitim almaktadır.

\subsection{Veri Toplama}

$\mathrm{Bu}$ araştırma, Burdur Mehmet Akif Ersoy Üniversitesinde lisansüstü eğitimine devam eden öğrencilerle gerçekleştirilmiş olup, tek aşamalı kümeleme örneklemi kullanılarak katılımcılara ulaşılmıştır. Tek aşamalı kümeleme örneklemine evren küçük ve kümeler sayısı az ise bir kural olmaksızın tesadüfen tek aşamada seçilebilir (Tezcan, 2017).

Araştırma verileri yarı yapılandırılmış görüşme formu ile toplanmıştır. Nitel araştırmada kullanılan bu formda sorular önceden hazırlanmış ve katılımcılardan sorulan sorulara yanıt verilmeleri istenmiştir. 
Türköz, O., Bektaş, M., Çiçek, H.

\subsection{Etik Prosedür}

Çalışma için Burdur Mehmet Akif Ersoy Üniversitesi Girişimsel Olmayan Klinik Araştırmalar Etik Kurulundan GO 2021/143 karar numaralı ve 07.04.2021 tarihli "Etik Kurul Onayı" alınmıştır. Çalışma etik kurul izni alındıktan sonra başlamıştır. Görüşmelerde katılımcıların gerçek isimleri yerine takma isimler kullanılmıştır. Görüşme öncesi katılımcılara çalışmanın amacı hakkında aydınlatıcı bilgi verilmiş ve katılım sağlama konusunda izinleri alınmıştır.

\subsection{Veri Analizi}

Veriler bilgisayar ortamına aktarılmış ve betimsel analiz tekniği ile çözümlenmiştir. Betimsel analiz tekniğinde görüşme soruları yöneltilen katılımcıların görüşlerini etkili bir biçimde yansıtmak amacıyla alıntılara yer verilir (Yıldırım \& Şimşek, 2013). Çalışma grubunda yer alan öğrencilere takma isimler verilerek gerekli alıntılar yapılmıştır.

\section{BULGULAR}

Araştırma bulguları, betimsel analiz tekniğine uygun olarak katılımcıların verdikleri cevaplardan doğrudan alıntılamalar yaparak verilmiştir.

\subsection{Neden Lisansüstü Eğitim?}

Neden lisansüstü eğitim sorusuna katılımcılar genel olarak akademik kariyer planlarının olduğunu belirtmişlerdir.

"Yeni mezun oldum KPSS hazırlanmıştım atamam daha olmadığı için bir B planı olarak lisansüstü eğitimi tercih ettim (Iş11)”.

“Akademik alanda ilerlemek istiyorum o yüzden lisansüstü eğitimi tercih ettim (Ayşe).”

"Kendimi muhasebe ve finansman alanında geliştirmek için (Ünal)".

"Rehberlik mesleğimi yapamadığım için farklı bir meslek alanında kendime firsat sunabilmek için lisansüstü eğitim tercihim oldu" (Sabri).

"Hocalarımın saygınlığını görünce bu hayalim ortaya çıktı (Güneş)”.

“Okumayı ve kendimi geliştirmeyi seviyorum bu yüzden lisansüstü eğitim (Ali)”.

"Hayalim öğretmen olmaktı bir şeyler öğretmek ve öğrenmek benim için çok önemli aynı zamanda kendimi bu alanda geliştirmek istiyorum o nedenle lisansüstü eğitimi tercih ettim (Gamze)". 
Grafik 1. Lisansüstü eğitim yapma nedeni

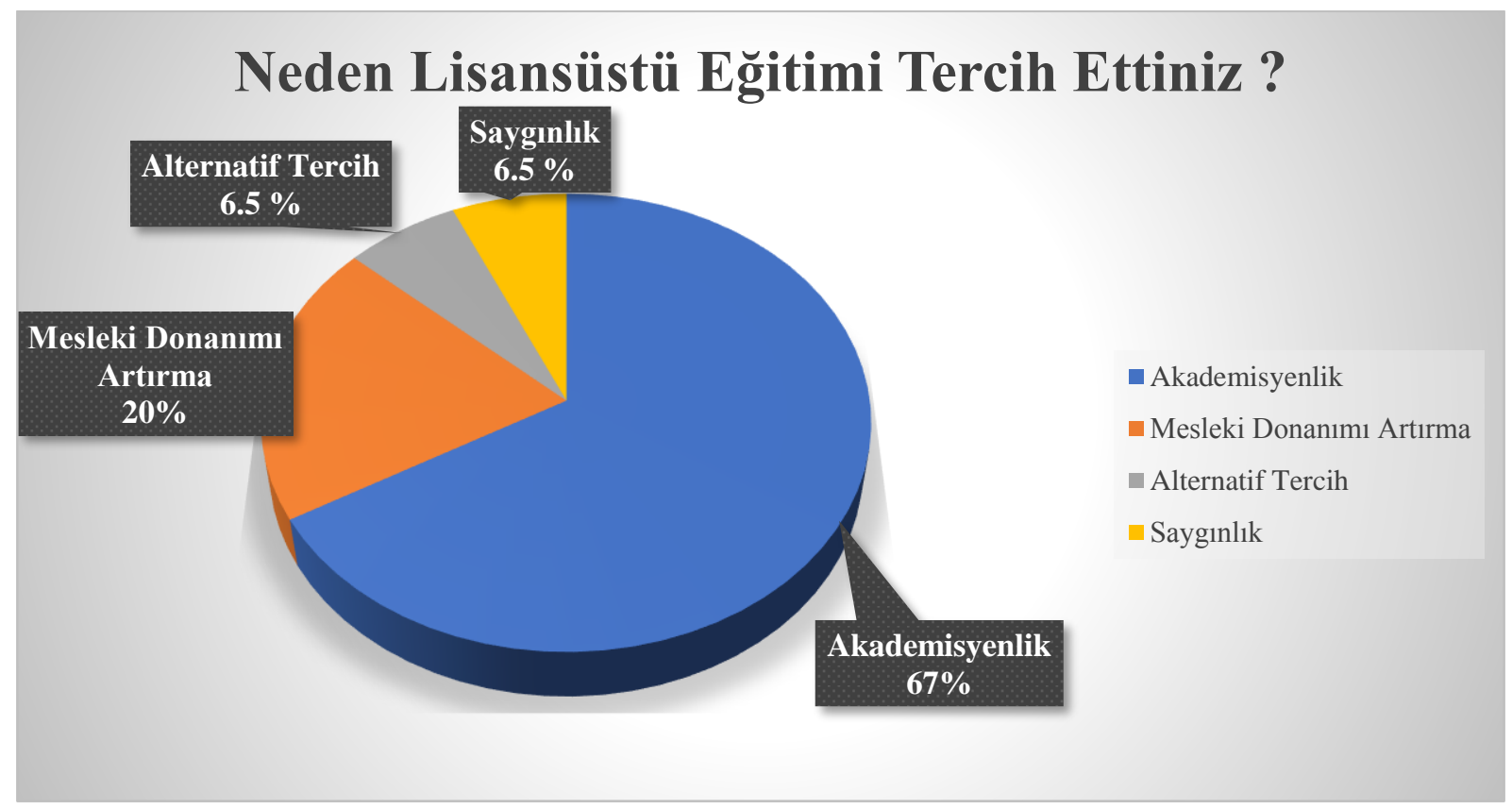

Yapılan çalışma neticesinde sorulan sorulardan "Neden lisansüstü eğitimi tercih ettiniz?” sorusuna katılımcılardan 10'u akademisyen olma nedenini içinde barındıran cevaplar vermiştir. Bu cevap \%67 oranla akademisyenlik yanıtı en fazla yanıt alan cevap olmuştur. 3 katılımcı mesleki olarak donanım kazanmak için lisansüstü eğitimi tercih ettiklerini belirtmişlerdir. 1 katılımcı alternatif bir tercih olarak, yine 1 katılımcı lisansüstü eğitimin saygınlık kazandırdığını düşünerek lisansüstü eğitimi tercih ettiklerini belirtmişlerdir. Sonuç olarak bu soru neticesinde lisansüstü eğitim alan bireylerin büyük bir çoğunluğunun ulaşmak istediği hedef noktası akademisyenlik olarak belirlenmiştir. Bu grubu \%20’lik oran ile lisans eğitimi aldıkları alanda gelişmek ve mesleki açıdan donanımlı olmak için lisansüstü eğitimi tercih eden bireyler izlemektedir. Bireylerin \%6,5'inin lisansüstü eğitimi hedeflediği mesleğe bir alternatif oluşturmak amacıyla tercih ettiği belirlenmiştir. Katılımcıların yine aynı oranda, saygınlık kazandırdığı için lisansüstü eğitim tercih ettikleri belirlenmiştir.

\subsection{Sizi Lisansüstü Eğitim Almaya Teşvik Eden Etmenler Nelerdir?}

Sizi lisansüstü eğitim almaya teşvik eden etmenler nelerdir sorusuna katılımcıların, üniversite hocaları, akademik kariyer, kendilerini geliştirme gayeleri, öğrenmeyi ve öğretmeyi sevmeleri gibi cevaplar verdikleri görülmüştür.

"Üniversite hocam yöneltti, bana sende lisansüstü eğitim almalısın dedi, başarırsın ilerlersin diyerek beni güdüledi beni yönelten bu oldu (Işı1l)”.

"Akademik alanda çalışma azmim beni buraya yöneltti (Fatih)".

“Hem akademik kariyer hem de mali müşavirlik yapmak istemem yöneltti (Ünal) “. 
"İşimi yapamadığım için lisansüstü eğitimde bir gelecek gördüğüm için son olarak da ailemin etkisi beni yöneltti (Sabri)".

"Lisansüstü eğitime beni yönelten lisans döneminde okuduğum işletme bölümümün bana olan katkıları (Erol)".

"Bilimsel dünyada yani akademik kariyer çatısı altında varlık gösterme isteğim yöneltti (Güneş)".

"Ekonomik açıdan bağımsızlı̆̆ımı kazanmış olmak ve kendimi bu alanda başarılı bulacağıma inanmak (Ali)”.

Grafik 2. Lisansüstü eğitim almaya teşvik eden etmenler



Yapılan çalışma neticesinde sorulan sorulardan "sizi lisansüstü eğitim almaya teşvik eden etmenler nelerdir?" sorusuna katılımcılardan 6 katılımcı akademik kariyer yapma düşüncesinin lisansüstü eğitim almaya teşvik ettiğini belirtmiştir. Bu cevap \%43 oranla en fazla yanıt alan cevap olmuştur. 3 katılımcı üniversite hocaları cevabını vermiştir. 3 katılımcı öğrenme ve öğretme sevgisi cevabını vermiştir. 2 katılımcı kişisel gelişim cevabını vermişti. 1 katılımcı ise iyi bir gelecek kurma isteği cevabını vermiştir. Sonuç olarak akademik kariyer cevabı sorunun hedef noktasını oluşturmaktadır.

\subsection{Lisansüstü Eğitimin Sonunda Ne Yapıyor Olacaksınız?}

Lisansüstü eğitimin sonunda ne yapıyor olacaksınız sorusuna katılımcılar, akademisyenlik, doktora eğitimi alıyor olmak, memur olmak ve kendi ilgi alanımda işimi yapıyor olarak ifadeleri kullanmışlardır. 
"Muhasebe anabilim dalında kendimi daha çok geliştirmiş olarak görüyorum (Fatih)".

"Kendime seçenekler sundum, kendimi akademisyen veya mali müşavir olarak görüyorum (Ünal)”.

"Üniversitede kadro almış olmak veya rehberlik için gerekli belgeleri sağladıktan sonra rehberlik yapıyor olacağım (Sabri)".

"Memur olmak ya da özel sektörde bir iş yapıyor olacağım (Ayşegül)".

"Doktora eğitimim için şimdiden uğraşıyorum eğitimim sonunda doktora eğitimi alıyor olacağım (Gamze)".

Grafik 3. Lisansüstü eğitimin sonunda yapılacaklar

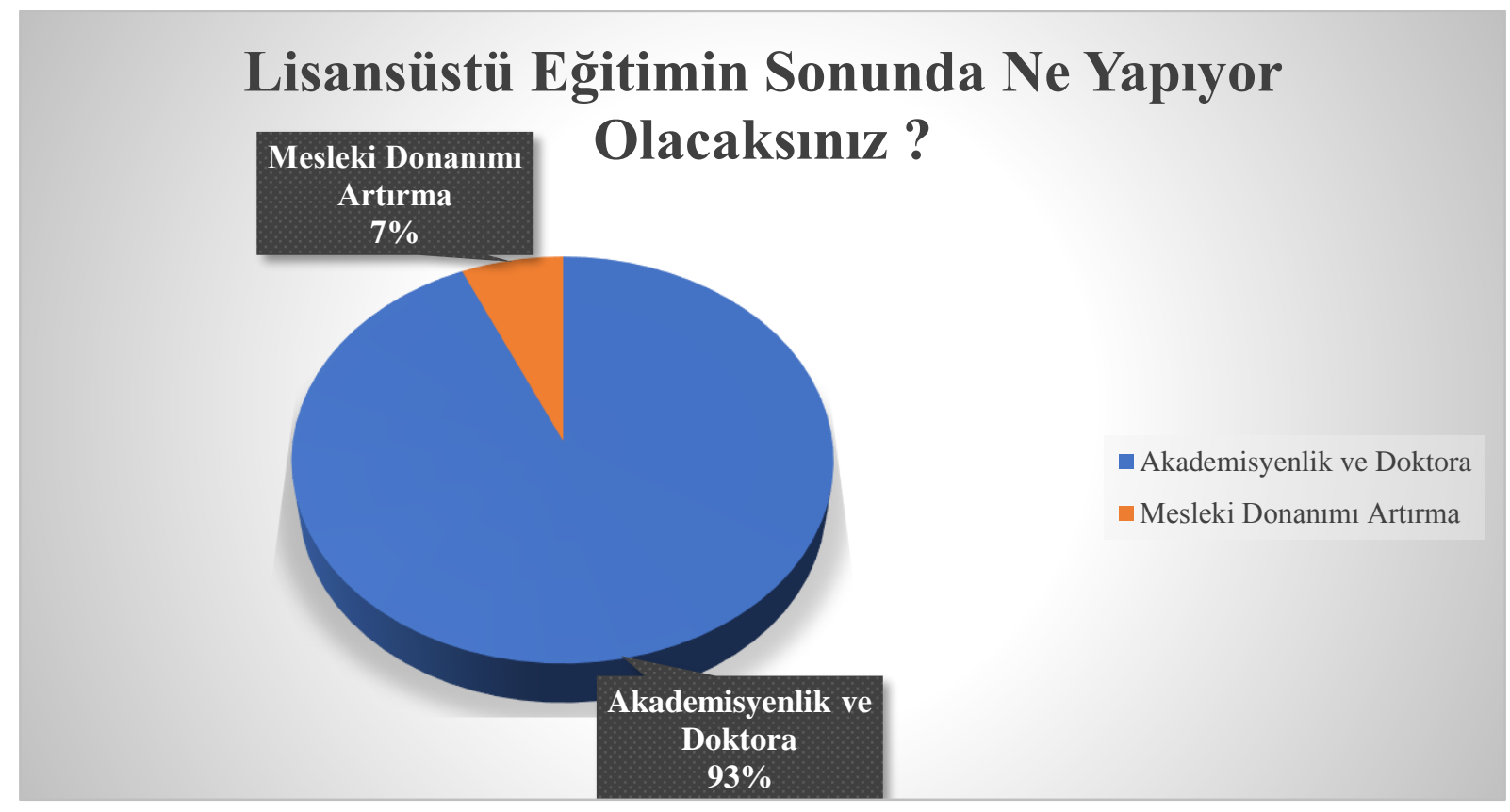

Yapılan çalışma neticesinde sorulan sorulardan "Lisansüstü eğitimin sonunda ne yapıyor olacaksınız?" sorusuna katılımcılardan 14 katılımcı akademisyenlik görevini yapıyor olma ve doktora eğitimi almak cevabını vermişlerdir. Bu cevap \%93 oranla en fazla yanıt alan cevap olmuştur. Katılımcıların 1 tanesi ise mesleki donanımı artırma cevabını vermiştir. Sonuç olarak öğrencilerin büyük bir bölümü akademisyenlik görevini yapıyor olmak ve doktora eğitimini almak istemesi hedef noktasını oluşturmaktadır.

\section{4. İş Bulma Kaygınız Devam Edecek Mi?}

İş bulma kaygınız devam edecek mi? sorusuna katılımcıların bazıları iş bulma kaygısının iş bulana kadar devam edeceğini, bazı katılımcılar ise aldıkları eğitim sonucunda bu kaygının ortadan kaybolacağını dile getirmişlerdir.

"Günümüz şartlarında iş bulma kaygısının iş bulana kadar devam edeceğini düşünüyorum (Fatih)". 
"Evet, çünkü eğitimi bitirsem bile gerekli şartlar beni zorlayacak bu yüzden iş bulma kaygım devam edecek (Ayşe)".

“İş bulma kaygım öğrenciyken olur ancak bitirince bir kaygım olacağını düşünmüyorum (Oğuzhan)".

"Evet devam edecek gibi duruyor turizm ile ilgili olan mesleğimi yapamıyorum sektörde dalgalanma çok ama lisansüstü eğitim yaparak bunu en aza indirmeye çalışıyorum (Sabri)".

“İş bulma kaygım devam etmeyecek kendimi geliştirdikten sonra kapıların açılacağını düşünüyorum (Gamze)".

Grafik 4. İş bulma kaygısı

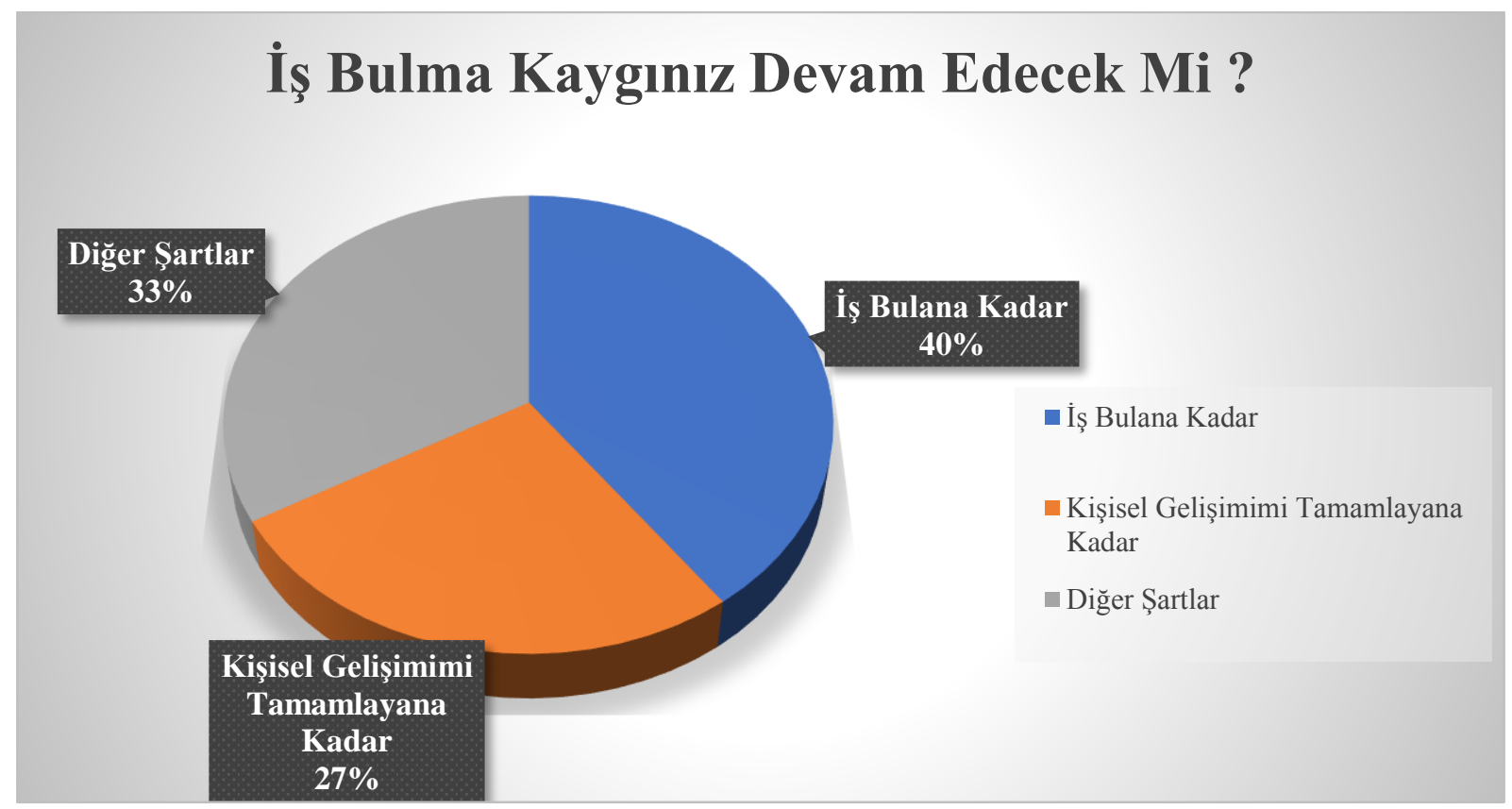

Yapılan çalışma neticesinde sorulan sorulardan “İş bulma kaygınız devam edecek mi?” Sorusuna katılımcılardan 6'sı iş bulma kaygısının bir iş bulana kadar devam edeceği cevabını vermişlerdir. Bu cevap \%40 oranla en fazla yanıt alan cevap olmuştur. 5 katılımcı diğer çeşitli şartlar olarak cevap vermişlerdir. 4 katılımcı ise kişisel gelişimlerinin tamamlayana kadar cevaplarını vermişlerdir. Sonuç olarak katılımcıların iş bulma kaygılarının kendilerinin bir iş bulana kadar devam edeceği sorunun hedef noktasını oluşturmaktadır.

\subsection{Gelecek Kaygınızı Gidermek İçin Kendinize Nasıl Katkılar Sağladınız?}

Gelecek kaygınızı gidermek için kendinize nasıl katkılar sağladınız sorusuna katılımcılar, ders çalışarak, alanımla ilgili kitaplar okuyarak, gerekli sınav puanlarını sağlayarak, farklı meslek gruplarında iş tecrübesi edinerek gibi yanıtlar vermişlerdir.

"Hedeflediğim noktalara ulaşmak için her zaman elimden geleni yaptım, tek bir noktaya odaklanmadım alternatif planlarım her zaman oldu (Işı1)”. 
“Kendimi sürekli geliştirerek günümüz şartlarına ayak uydurmaya çalışıyorum ona göre bir çalışma yapıyorum (Fatih)".

"Ders çalışarak katkı sağlıyorum bu durum benim psikolojik destek almamı bile gerektirdi (Ayşe)".

"ALES ve YDS puanlarımı alarak ilerisi için bir basamak oluşturdum (Oğuzhan)".

"Kendimi alanım ile ilgili antrenörlük belgeleri alarak bir katkı sağladım (Ahmet)".

"Rehberlik mezunu olduğum için saha içi çalışmalarım oldu kendime tecrübe kazandırdım (Sabri)".

“Online eğitimlere katılarak farklı alanlarda kendimi katkı sağlıyorum (Ayşegül).”

"Elimden geleni yapıyorum sınavlar için kendimi hazırlıyorum (Erol)".

"Görev ve sorumluluğum ne var ise onu yapmaya her zaman çalıştım (Ali)".

“Gelecek kaygımı gidermek için kendi alanım olmayan farklı meslek gruplarında kendime tecrübeler kazandırıyorum (Dilara)".

Grafik 5. Gelecek kaygısını gidermek için yapılanlar

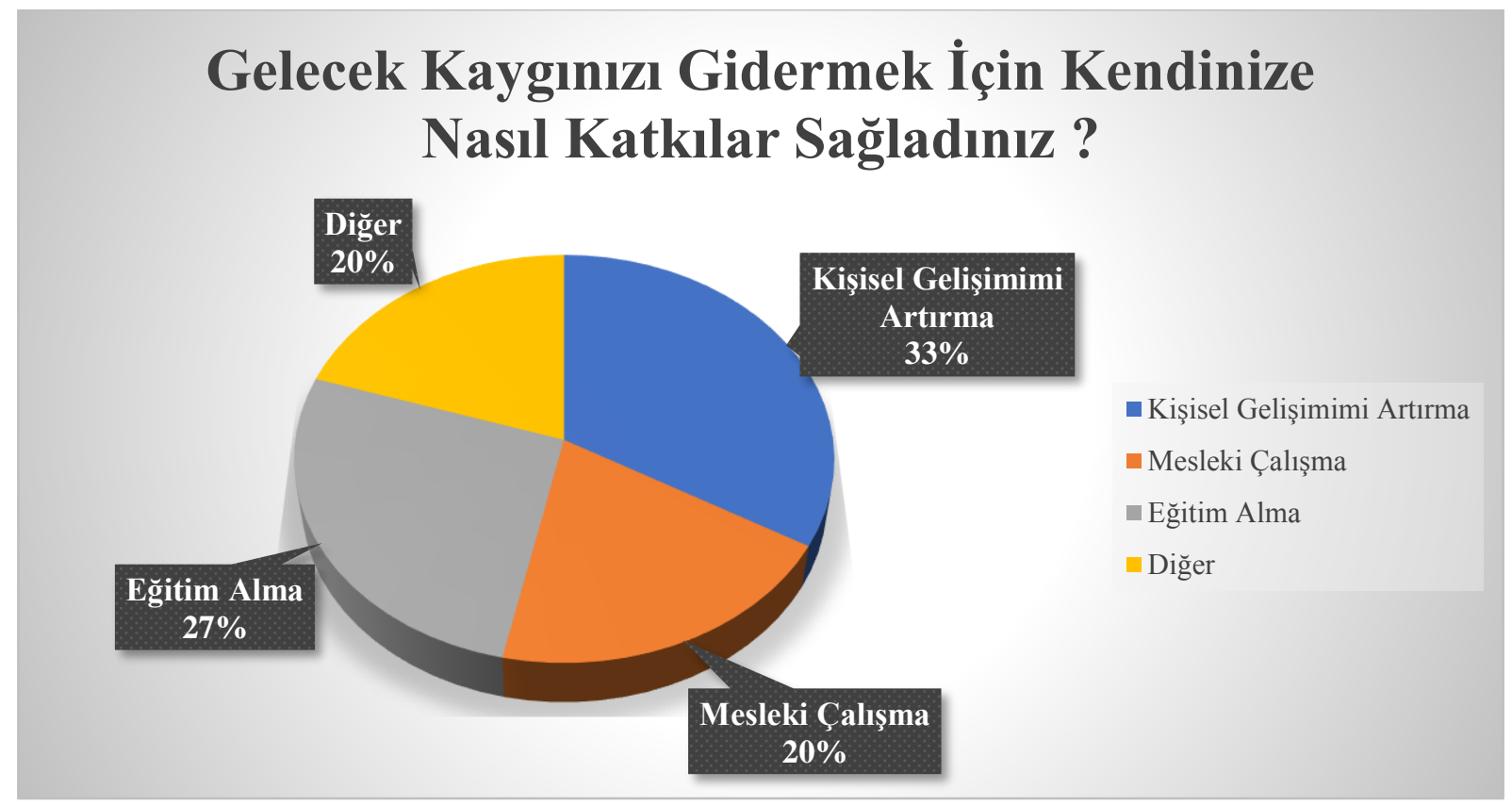

Yapılan çalışma neticesinde sorulan sorulardan "Gelecek kaygınızı gidermek için kendinize nasıl katkılar sağladınız?” Sorusuna katılımcılardan 5 öğrenci kişisel gelişimi artırma cevabını vermişlerdir. Bu cevap \%33 oranla en fazla yanıt alan cevap olmuştur. 4 katılımcı eğitim alma cevabını vermiştir. 3 katılımcı mesleki eğitim cevabını vermişlerdir. 3 katılımcı ise diğer olarak cevaplandırmıştır. Sonuç olarak kişisel gelişime önem vermenin gelecekte yaşanacak kaygıyı azaltacağı düşünülmektedir. $\mathrm{Bu}$ cevap sorunun hedef noktasını oluşturmaktadır. 
Türköz, O., Bektaş, M., Çiçek, $H$.

\subsection{Lisansüstü Eğitimde Danışmanlık Size Neler Kazandırdı?}

Lisansüstü eğitimde danışmanlarınız size neler kazandırdı sorusuna katılımcılar bazıları danışmanları için yol gösterici olduğunu gerekli bilgileri sağlayarak 1şık tuttuğunu söylerken bazı katılımcılar ise danışmanlarından yararlanamadıklarını dile getirmişlerdir.

"Danışmanıma her zaman iletişim sorunu yaşadım açıkçası benimle ilgilenme konusunda sorunlarımız vardı çok fazla bir şey kazandıramadı (Ahmet)".

"Danışman hocamla çok fazla bir konuşma yapamadım çünkü yeni eğitime başladığım için (Güneş)".

"Pandemi süreci olmasa idi daha fazla katkı sağlayacağını düşünüyorum ancak Akademik anlamda beni aydınlattı (Ali)".

"Danışmanım sayesinde neye nasıl bakmam gerekir ve gerekli olan adımlar ne olmalı gibi sorularıma her zaman cevap oldu (İrem)".

"Açıkçası bana bir katkı sağlamadı çalıştı̆̆ım için fazla bir etkileşime geçemedim (Dilara)".

Grafik 6. Lisansüstü Eğitimde Danışmanın Kazandırdıkları

\section{Lisansüstü Eğitimde Danışmanlık Size Neler Kazandırdı ?}

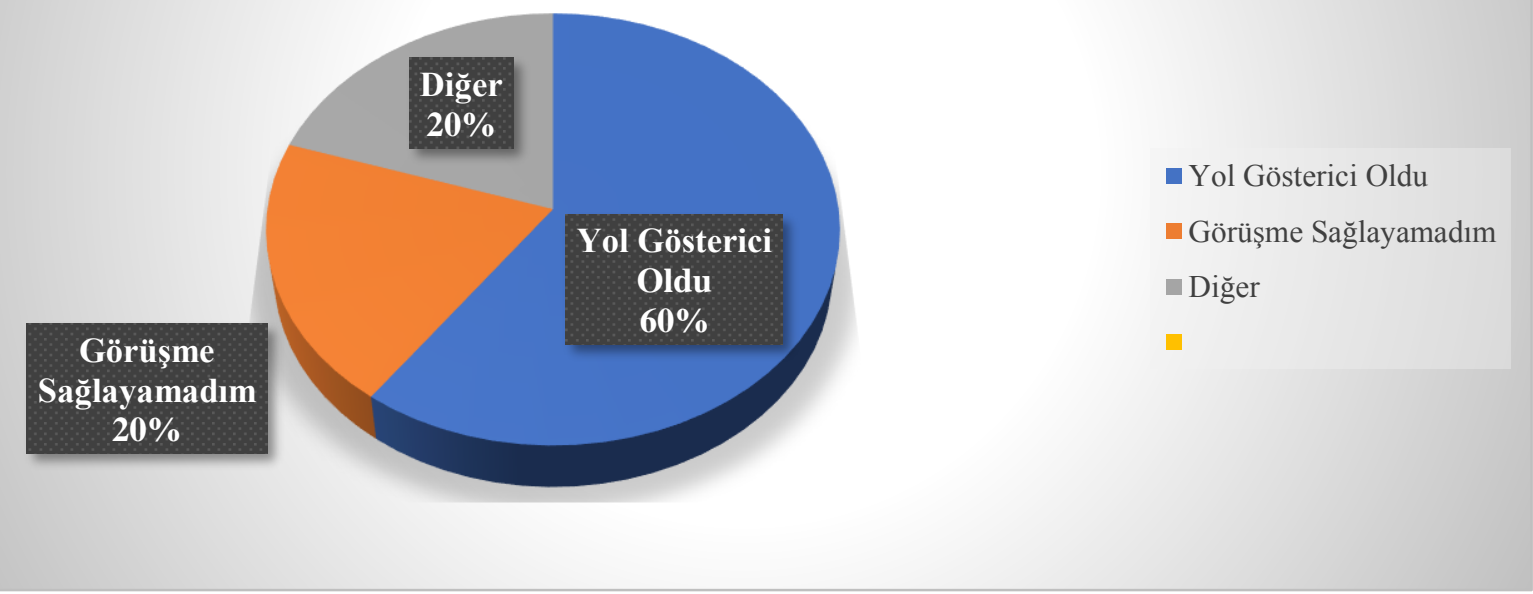

Yapılan çalışma neticesinde sorulan sorulardan "lisansüstü eğitimde danışmanlık size neler kazandırdı?” Sorusuna katılımcılardan 9'u danışmanlarının yol gösterici olduğu cevabını vermişlerdir. Bu cevap \%60 oranla en fazla yanıt alan cevap olmuştur. 3 katılımcı danışmanları ile görüşme sağlayamadıkları cevabını vermişlerdir, 3 katılımcı ise diğer cevabını vermişlerdir. Sonuç olarak danışmanlarının yol gösterici olduğu katılımcıların cevaplarının büyük bir kısmını oluşturmaktadır. Bu cevap sorunun hedef noktasını oluşturmaktadır. 


\subsection{Lisansüstü Eğitimde Karşılaştığınız En Büyük Sorun Nedir?}

Lisansüstü eğitimde karşılaştığınız en büyük sorun nedir sorusuna katılımcılar, yapılan çalışmalarının beğenilmemesi, pandemi süreci, liyakatsiz atamalar, tez süreci, iş yoğunluğu olarak cevap vermişlerdir.

"Yaptığım çalışmalar, ödevler beni her zaman zorluyor ve yaptıklarımın beğenilmemesi benim için en büyük problem (Iş11)”.

"Derslerin ilerleyişi konusu hakkındaki yetersizlik benim için en büyük sorun (Fatih)".

“Tez konusunda zorlanacağımı düşünüyorum benim için en büyük sorun bu (Ünal)”.

"Liyakatsizlik ve derslerimin bana katkı sağlamaması (Ahmet)".

"Lisansüstü eğitimde beklentim fazlaydı ancak bunu göremedim bu benim en büyük problemim (Sabri)".

"Derslerin uzaktan eğitim olması faydalı olduğunu düşünmüyorum (Erol)".

"Literatürü takip etmek konusunda sorunlarım var kendimi lisansüstü eğitime adapte edemedim eğitim süreci lisans eğitimden farklı (Güneş)".

“Aldığım bir ders ile ilgili bir program bilmem gerekiyordu onu öğrenmek için uğraştım benim için en büyük problem o olabilir (Gamze)”.

"Büyük bir sorun ile karşılaşmadım hepsinin üstesinden geldim (İrem)".

"Çalıştığım için çalışmalarıma vakit ayıramıyorum benim için en büyük sorun bu (Dilara)".

Grafik 7. Lisansüstü eğitimde karşılaşılan zorluklar

\section{Lisansüstü Eğitimde Karşılaştığınız En Büyük Zorluk Nedir?}

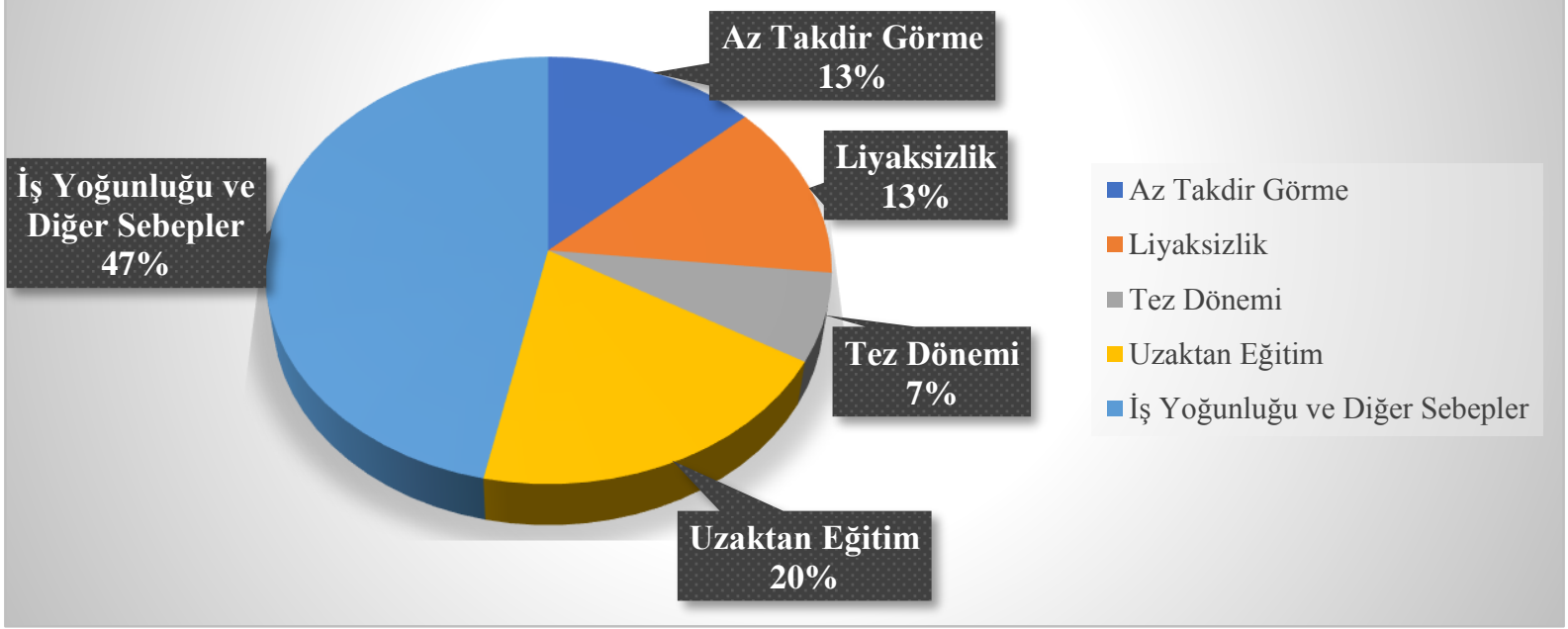




\section{Türköz, O., Bektaş, M., Çiçek, H.}

Yapılan çalışma neticesinde sorulan sorulardan “Lisansüstü Eğitimde Karşılaştığınız En Büyük Zorluk Nedir?” Sorusuna katılımcılardan 7 katılımcı iş yoğunluğu cevabını vermiştir. $\mathrm{Bu}$ cevap \%47 oranla en fazla yanıt alan cevap olmuştur. 3 katılımcı uzaktan eğitim cevabını vermiştir. 2 katılımcı liyakatsizlik cevabını vermiştir. 2 katılımcı az takdir görme cevabını vermiş̧tir. 1 katılımcı ise tez dönemi cevabını vermiştir. Sonuç olarak bu soruda iş yoğunluğu sorunun hedef noktasını oluşturmaktadır.

\section{SONUÇ}

Gelecek kaygısı yaş fark etmeksizin hayattan beklentisi olan her bireyin yaşayabileceği bir durumdur. Kimi bireyler bu durumu minimal seviyede, kendi yaşam standartlarına yansıtmadan kimi bireyler ise yoğun bir şekilde, rutin yaşamını değiştirecek şekilde yaşayabilmektedir. Hayatın her döneminde karşımıza çıkabilecek olan bu durumun çoğunlukla eğitim hayatı son bulmaya yakın bireyleri etkisi altına alabilmektedir. Bu konu etrafında şekillenen ve lisansüstü öğrencilerin gelecek kaygısının belirlenmesine yönelik yapılan çalışmada genel olarak katılımcıların gelecekle ilgili iyimser düşüncelere sahip olduğu görülmektedir. Lisansüstü eğitimi bitirince bireylerin akademisyen olacağı düşüncesi bu iyimserliğin nedeni olabilir. Çünkü katılımcıların büyük çoğunluğunun lisansüstü eğitimi, bireyleri akademisyenlik mesleğine ulaştırabilecek bir yol olarak gördüğü belirlenmiştir. Ayrıca katılımcıları lisansüstü eğitim almaya teşvik eden etmenlerin başında akademik kariyer yapma isteğinin olması bu düşünceyi destekler niteliktedir. Bu düşünceyi öğrencilere lisansüstü eğitim hayatı sona erdiğinde kendilerini nerede gördükleri sorulduğunda katılımcıların en fazla cevap olarak akademisyenlik mesleğini yapıyor olmak cevabı da desteklemektedir.

Katılımcıların iş bulma kaygısının, kişisel gelişimlerini tamamladıktan sonra büyük çoğunlukla sona ereceği düşüncesinde oldukları görülmüştür. Katılımcılar, gelecek ile ilgili kaygılarını gidermek için kişisel gelişime önem verdiklerini ve eğitimlerine devam ettiklerini belirtmişlerdir.

Bulgular incelendiğinde lisansüstü eğitimlerine devam eden katılımcıların akademisyen olma hayallerinin olduğu görülmüştür. Bu hayalin ise katılımcıları, gelecekle ilgili iyimser düşünmeye ittiği düşünülmektedir. Kişisel gelişimine önem veren ve gelişimlerini sürdüren katılımcıların eğitim konusunda farkındalığının yüksek olmasının da gelecekle ilgili kaygılarını azalttığı düşünülmektedir.

Literatürde konu ile ilgili olarak çeşitli çalışmaların olduğu görülmüştür. Kula ve Saraç (2016)' 'n üniversite öğrencilerinin gelecek kaygıları ile ilgili yapmış oldukları çalışmalarında öğrencilerin not ortalamaları, aile baskısı, gelir düzeyleri ile kaygı durumunu ölçmeyi hedeflemişlerdir. Araştırma sonuçlarına göre; cinsiyet, fakülte/yüksekokul, anne-baba tutumu, 


\section{MAKÜ-BIFD 4(2), 132-152, 2021}

ailenin ortalama aylık geliri ve barınılan yer değişkenlerine göre öğrencilerin sürekli kaygı düzeyleri arasında istatistiksel açıdan anlamlı farklılıkların olduğu ortaya çıkmıştır. Yapılan bu çalışma da ise lisansüstü eğitim alan öğrencilerin öğrenimlerini bitirdikleri zaman iş bulma kaygılarının ve kaygı nedenlerinin temeline dayanan sorunlara odaklanılmıştır. Aygün (2014) öğrencilerin yaşam amaçlarıyla gelecek kaygısı arasındaki ilişki isimli çalışmasında ortaöğretimde okuyan öğrencilerin yaşam amaçlarıyla gelecek kaygısı arasındaki ilişkiyi tespit etmeye çalışmıştır. Araştırma ile öğrencilerin cinsiyetleri, okul türleri, not ortalaması ve ailenin tutumu gibi çeşitli demografik özelliklerine göre yaşam amaçları ve gelecek kaygısı arasındaki farklılıkları tespit ederek diğer araştırmalara ve hazırlanacak programlara 1şık tutmak hedeflenmiştir. Dursun ve Aytaç (2012) üniversite öğrencilerinin iş gücü piyasasına yönelik beklentileri ve kaygı düzeyleri arasındaki ilişki isimli çalışmalarında üniversite son sınıfta öğrenim gören öğrencilerin kaygı ve umutsuzluk düzeylerini tespit etmek ve öğrencilerin kayg1 ve umutsuzluk düzeyleri ile iş bulma ümidi, iş deneyimi, iş önceliği gibi işgücü piyasasına ait beklenti ve deneyimleri arasında bir ilişki olup olmadığını ortaya koymaya çalışmışlardır. Üniversite son sınıf öğrencilerinin katılımıyla yapılan çalışmada mezun olduktan sonra iş bulma konusunda ümidi olmayan öğrencilerin sürekli ve durumluk kaygı ile umutsuzluk düzeyleri, iş bulma konusunda ümidi olanlara göre oldukça yüksek bulunmuştur. Kara vd. (2020)'lerinin yapmış olduğu araştırma sonucuna göre, çalışmaya katılanların orta düzeyde gelecek kaygısı (umutsuzluk) yaşadıkları, kadınların erkeklerden daha yüksek umutsuzluk düzeyine sahip olduğu ve sınav kaygısı ile gelecek kaygısı (umutsuzluk) düzeyi arasında anlamlı pozitif bir ilişki olduğu bulunmuştur. Bu çalışma sonucunda ise kadın katılımcıların kişisel gelişimlerine yatırım yaparak iş bulma kaygısını en az seviyeye indirdikleri görülmüştür.

$\mathrm{Bu}$ çalışma sonucuna göre, lisansüstü eğitimleri döneminde bireylerin akademisyen olmayı hayal ettiği ve gelecekte kendilerini akademisyen olarak gördükleri görülmüştür. Lisansüstü eğitime devam eden bireylere eğitimlerini tamamlayınca direk akademisyen olamayacakları çünkü akademisyenlik mesleği ile ilgili daha fazla çalışmaların gerekli olduğu anlatılmalı ve bu süreçte öğrencilere, akademik anlamda kendilerini geliştirebilecekleri adımlar danışman öğretim elemanları tarafından detaylı bir şekilde aktarılarak yol gösterilmelidir. Lisansüstü eğitim alan bireylerin farkındalıklarının arttırılabileceği yeni çalışmalar yapilmalidır.

Bu çalışmanın eğitim ve kaygı gibi konular etrafında şekillenecek çalışmalara yardımcı olacağı ve literatüre katkı sağlayacağı düşünülmektedir. 


\section{Türköz, O., Bektaş, M., Çiçek, H.}

\section{KAYNAKÇA}

Akçok, B. (2018). Gelecek kaygısı nedir? https://www.bilgiustam.com/gelecek-kaygisi-nedirsebepleri-ve-etkileri-nelerdir

Akgün, A., Gönen, S., \& Aydın, M. (2007). İlköğretim fen ve matematik öğretmenliği öğrencilerinin kaygı düzeylerinin bazı değişkenlere göre incelenmesi. Elektronik Sosyal Bilimler Dergisi, 6(20), 283-299.

Akmaz, G., \& Ceylan, N. (2009). Fen edebiyat fakültesi Türk Dili ve Edebiyatı Bölümü öğrencilerinin durumluk-sürekli kaygı düzeyleri ve kaygı nedenleri (Tokat Örneği). Sosyal Bilimler Araştırmaları Dergisi, 1, 131-147.

Alisinanoğlu, F., \& Ulutaş, İ. (2003). Çocukların kaygı düzeyleri île annelerinin kaygı düzeyleri arasındaki ilişkinin incelenmesi. Eğilim ve Bilim, 28(128), 65-71.

Anonim. (2020). Türk eğitim sistemi. Fulbright Türkiye. https://fulbright.org.tr/turk-egitimsistemi

Aydoğdu, $\quad$ Y. $\quad$ (2021, $\quad$ A ğustos 16). Gelecek kaygıs1. https://www.milliyet.com.tr/pembenar/yasemin-aydogdu/gelecek-kaygisi-2852804

Bandura, A. (1991). Self-efficacy conception of anxiety. In Anxiety and self-focused attention. (pp. 89-110). Harwood Academic Publishers.

Büyüköztürk, Ş. (1997). Araştırmaya yönelik kaygı ölçeğinin geliştirilmesi. Kuram ve Uygulamada Eğitim Yönetimi, 12(12), 453-464. https://dergipark.org.tr/tr/pub/kuey/127044

Çakmak, Ö. (2008). Eğitimin ekonomiye ve kalkınmaya etkisi. Dokuz Eylül Ziya Gökalp Eğitim Fakültesi Dergisi, 11, 33-41.

Çetiner Aydın, P. (2019). Kaygı ve endişe. Turkiye Klinikleri J Psychiatry-Special Topics, 10(4), 228-236.

Doğan, A. A. (2003). Beden eğitimi ve spor bölümü öğrencilerinin durumluk kaygı düzeyleri ile başarıları arasındaki ilişkileri. Beden Eğitimi ve Spor Bilimleri Dergisi, 5(3), 1-5.

Erozkan, A. (2011). Investigation of factors predicting the anxiety level of university senior students. International Online Journal of Educational Sciences, 3(2), 776-805. www.iojes.net

Ertürk, S. (1988). Türkiye'de eğitim felsefesi sorunu. Hacettepe Üniversitesi Eğitim Fakültesi Dergisi, 3, 11-16.

Göçer, A. (2013). Türkçe öğretmeni adaylarının dil kültür ilişkisi üzerine görüşleri: fenomenolojik bir araştırma. Erzincan Üniversitesi Eğitim Fakültesi Dergisi, 15(2), 26.

Kartopu, S. (2013). Kaygının kader algıları ile ilişkisi (Kahramanmaraş örneği). Gümüşhane Üniversitesi İlahiyat Fakültesi Dergisi, 2(3), 238-260.

Kaya, V., \& Varol, K. (1999). İlahiyat fakültesi öğrencilerinin durumluk-sürekli kayg1 düzeyleri ve kayg1 nedenleri (Samsun örneği). Doğu Batı Dergisi, 2(6), 37.

Kozacıŏlu, G. (1986). Çocukların Anksiyete Düzeyleri İle Annelerim Tutumları Arasındaki İlişki.

Kula, K. Ş., \& Saraç, T. (2016). Üniversite öğrencilerinin gelecek kaygısı. Mustafa Kemal Üniversitesi Sosyal Bilimler Enstitüsü Dergisi, 13(33), 227-242.

Meb. (2021). Türkiyede Bulunan Lise Türleri. 
Mevzuat Bilgi Sistemi-Lisansüstü Eğitim Yönetmeliği. (n.d.). https://www.mevzuat.gov.tr/mevzuat?MevzuatNo=21510\&MevzuatTur=7\&MevzuatTertip=5 Özyılmaz, Ö. (2017). Türk milli eğitim sisteminin sorunları ve çözüm arayışları (5. Bs.). Pegem Akademi. https://doi.org/10.14527/9786055885809

Sevinç, B. (2002). Türkiye' de lisansüstü eğitim uygulamaları, sorunlar ve uygulamalar. Ankara Universitesi Egitim Bilimleri Fakultesi Dergisi, 34(1), 1-13. https://doi.org/10.1501/egifak_0000000052

Tektaş, N. (2014). Üniversite mezunlarının kaygsı düzeylerinin incelenmesi. Selçuk Üniversitesi Sosyal Bilimler Enstitüsü Dergisi, Dr. Mehmet, 243-253.

Varış, F. (1972). Türkiye'de lisans-üstü eğitim pozitif bilimlerin temel ve uygulamalı alanlarında. Ankara Üniversitesi Eğitim Bilimleri Fakültesi Dergisi, 5(1), 1-24. https://doi.org/10.1501/egifak_0000000336

Yıldırım, A., \& Şimşek, H. (2013). Sosyal bilimlerde nitel araştırma yöntemleri. Seçkin Yayıncilik.

YÖK. (2021). Yükseköğretim Bilgi Sistemi Öğrenci Sayıları. https://istatistik.yok.gov.tr/

Zaleski, Z. (1996). Future anxiety: Concept, measurement, and preliminary research. Personality and Individual Differences, 21(2), 165-174. https://doi.org/10.1016/01918869(96)00070-0 